\title{
Pack for Sustainability: Navigating through Uncharted Educational Landscapes
}

\author{
Ólafur Páll Jónsson * (10 and Allyson Macdonald \\ School of Education, University of Iceland, 105 Reykjavik, Iceland; allyson@hi.is \\ * Correspondence: opj@hi.is
}

Citation: Jónsson, Ó.P.; Macdonald,

A. Pack for Sustainability: Navigating

through Uncharted Educational

Landscapes. Sustainability 2021, 13,

13555. https://doi.org/10.3390/

su132413555

Academic Editors: Joke Vandenabeele,

Mathias Decuypere, Katia Biedenkopf

and Matthias Lievens

Received: 1 November 2021

Accepted: 4 December 2021

Published: 8 December 2021

Publisher's Note: MDPI stays neutral with regard to jurisdictional claims in published maps and institutional affiliations.

\begin{abstract}
The worlds of education and learning have for the last few decades been characterized by reactions to the detrimental human impact on the environment, which is measured on such a scale that scholars now refer to the present epoch as the Anthropocene. In order to develop ideas and practices that could guide us into place-based research and an emancipatory relationship between pedagogy and knowledge, the focus needs to shift from what to teach and why (Knowledge and Curriculum) and concern over how learning is evaluated (Assessment) to how we should teach (Pedagogy). The acronym PACK (Pedagogy, Assessment, Curriculum, and Knowledge) turned into the idea of packing for a trip into uncharted educational territory, taking with us several gadgets that might be useful. Our own journey emerged as a dialogue between a philosopher and a science educator. Building on experiences from global work to regional research and a university chairmanship for sustainability, we tried to pack some big ideas for educators to take along, helping them navigate the educational landscapes ahead.
\end{abstract}

Keywords: sustainability education; educational change; crisis; curriculum; Basil Bernstein

\section{Introduction: Guiding Questions}

A model citizen of the modern world born in the year 2000 and growing up in the Millennium decades could have had —and should have had—opportunities to develop a sense of sustainability that builds on democratic values in the classroom, at school, and at district and national levels. However, having lived through the first couple of decades of the 21st century, many teenagers have a different experience. In a conversation during the early months of 2020, some teenagers remarked that they did not think of " 2020 " as referring to a year; it was more like a number with a life of its own. Asked to clarify, they responded: "It is more like a reference point, a destination. And this year many things will be postponed." Among the things postponed were several programs aimed at sustainability, inside and outside of education. The course is not set for 2030, but will that year also turn into a destination for postponing further action? Greta Thunberg has called for an immediate change:

We need to stop focusing on dates and numbers and actually accept and acknowledge the fact that we need to reduce our emissions right now. We can talk about 2030 or 2040 as much as we want. But it is what we are doing now that really matters. [1]

As far back as 2008, the U.S. National Science Foundation funded workshops across the United States with 2020 in mind. At one workshop held in Corvallis, Oregon in 2008, about 30 participants, including some well-known educators and researchers, were to address lifelong Science, Technology, Engineering, and Mathematics (STEM) learning in both practitioner and researcher communities. A well-known physics scholar mentioned the work What Teachers Need to Know about Language [2], and said she was not interested in telling teachers what to do "until we understand how children learn". At the global level, similar work had begun with support from UNESCO, such as the Decade of Education 
for Sustainable Development, which ran from 2005 to 2014. The world was ripe for critical approaches to education, reflected in scholars and teachers striving for educational improvement. However, education has not lived up to its promises; some say it is a part of the problem rather than the solution [3]. This means that we have to set a new course and we have some uncharted landscapes ahead of us. The year 2020 has passed, some say with little regret, and the next big milestone has long since been defined by the U.N. Sustainable Development Goals (UNSDG) as 2030. However, how do teachers make sense of this journey in their daily practices? How do we get to a 2030 that will not be a mere stepping stone for further disappointment and deferment? To support us on this journey, we have put some conceptual gadgets into a pack with four pockets (see Table 1). We can take this PACK on our journey to help us get to a destination that we can be content with.

Table 1. A PACK with guiding questions (gadgets) about educational design.

\begin{tabular}{cccc}
\hline & $\mathbf{P}$ & $\mathbf{A}$ & $\mathbf{C}$ \\
& Pedagogy & Assessment & Curriculum \\
\hline Gadgets & How do we teach students? & How do we evaluate learning? & What is to be taught? \\
\hline
\end{tabular}

The four gadgets in the above PACK — the questions on pedagogy, assessment, curriculum, and knowledge — can help us navigate through uncharted educational landscapes. The conventional way of using these gadgets, beginning furthest to the right and then moving from right-to-left, goes like this:

(K) gather experts to identify relevant knowledge and skills;

(C) organize these as objectives of formal education;

(A) devise a way of assessing the extent to which these objectives are met; and

(P) develop appropriate practices of the work of students that connect the knowledge $(\mathrm{K})$, the curricular objectives $(\mathrm{C})$, and the assessment $(\mathrm{A})$.

According to this logic, good educational design begins with (1) identifying relevant knowledge and skills as desired learning outcomes, then (2) translating the learning outcomes into curricula for regulating organized educational activities, (3) designing ways of evaluating to what extent these objectives have been met, and then (4) developing appropriate pedagogical approaches for teacher-student sessions. Some might want to reverse the order of (3) and (4), i.e., devise a way of teaching before designing a means of assessing to what extent the desired learning has taken place. Approaching things in this way, we take for granted certain understandings of the four questions. We call this "conventional understanding" of educational design.

When we as teachers PACK, we find that we already have something helping us along at each junction, whether we need something to direct us to the next point on a path, or we need to sit down, perhaps contemplating where we are, looking back and evaluating the trip up to now. When we refer to the bottom line in Table 2 as a conventional understanding of educational design we do, of course, make a generalization. When the physics scholar remarked that she was not ready to tell teachers what to do until they knew more about how students learn, she was expressing doubts about this conventional understanding. Likewise, when Jerome Bruner put forth the spiral curriculum in The Process of Education [4], following the Woods Hole conference in 1959, he was questioning the priority of knowledge in educational design and emphasizing the importance of understanding students' learning. Although radical at the time, and even today, these changes do not question the very idea of established knowledge as the starting point for educational design.

Table 2. The PACK with a conventional framing of educational design.

\begin{tabular}{|c|c|c|c|c|}
\hline & $\begin{array}{c}\mathbf{P} \\
\text { Pedagogy }\end{array}$ & $\begin{array}{c}\text { A } \\
\text { Assessment }\end{array}$ & $\begin{array}{c}\mathrm{C} \\
\text { Curriculum }\end{array}$ & $\begin{array}{c}\mathrm{K} \\
\text { Knowledge }\end{array}$ \\
\hline Gadgets & How do we teach students? & How do we evaluate learning? & What is to be taught? & What knowledge is needed? \\
\hline $\begin{array}{l}\text { Conventional } \\
\text { understanding }\end{array}$ & $\begin{array}{l}\text { Presentation of established } \\
\text { knowledge and training for } \\
\text { skills. }\end{array}$ & $\begin{array}{l}\text { Student is assessed, either } \\
\text { formatively or summatively. }\end{array}$ & $\begin{array}{l}\text { Curriculum defines objectives } \\
\text { and content of education. }\end{array}$ & $\begin{array}{l}\text { Knowledge building as an } \\
\text { accumulation of established } \\
\text { knowledge and skills. }\end{array}$ \\
\hline
\end{tabular}




\section{Educational Research and Design}

PACK-ing for educational design in times of crisis requires an engaged dialogue about the essence of education. Questioning educational design from the perspective of sustainability in the year 2021 makes us dive much deeper into the muddy waters of education than Bruner did during the educational crisis of the late 1950s or the participants in the above-mentioned conference in Oregon in 2008 could have envisaged. Generating a consensus about objectives is often seen as the first step in educational reform [5]. We believe, however, that reaching a consensus is neither realistic nor desirable for educational change but, rather, that it is the dialogue arising from conflicting views on both objectives and practices that should drive the project. John Dewey proposed something similar when arguing for the importance of democracy for education $[6,7]$ and various writers have pointed towards this path as both important and powerful [8,9].

Educational research has changed in size, scope, and color over the last 40 to 50 years; for professors in education in the 1950s and 1960s, the current field would be almost unrecognizable. When New Public Management took off in the 1990s, the management of research was affected and a trend towards quality assurance and assessment put its roots down [10]. Productivity became an important metric for ranking educational institutions, from primary education up to universities, with quality control adopted from business models becoming ever more present as an administrative ideal. At the same time, the gap between quantitative and qualitative research seemed to widen (again). The OECD supported national evaluations of educational research (IERD) and various international metrics became more important in the organization, administration, and politics of education, from early childhood education to higher education, the ranking systems of universities, the Bologna process in Europe, and the PISA and TALIS surveys by OECD.

This trend behind large international organizations has created larger systems of knowledge and opened new channels for knowledge generation and exchange, but at the same time marginalized various local sources of knowledge and, in some cases, narrowed the conception of accepted knowledge to that generated through "scientific" methods [11]. Such prevalence of "scientific" knowledge over other kinds of knowledge has been criticized in the humanities since the early decades of the $20^{\text {th }}$ century when logical positivism disappeared as a research project. Yet, knowledge qualified as "scientific", according to positivistic ideas, continues to prevail over other forms of knowledge [12].

Since the 1990s, neoliberalism has pulled education away from typical sustainability values towards values and practices that are unsustainable [3,13-16]. In an editorial to a special issue of Environmental Education Research on environmental education in a neoliberal climate, David Hursh, Joseph Henderson, and David Greenwood write:

It can be readily shown that neoliberal tenets have formed the core principles for primary, secondary, and higher education reform in many countries over the last two decades ... Leading Finnish educator Sahlberg (2011) writes that these countries adopt 'management and administrative models brought to schools from [the] corporate world' (203). Teaching, for example, is constrained by prescribed curriculum, and learning, evaluated through standardized tests. [13] (p. 306)

What Hursh et al. are referring to here is a reality that others have also observed, such as Stephen Sterling in his book Sustainable Education: Re-visioning Learning and Change. He notes that for decades, education has been identified as a key to addressing sustainability issues but, at the same time, most education reinforces unsustainable values and practices:

We are educated by and large to 'compete and consume' rather than to 'care and conserve'. Secondly, education is, as never before, subject to unremitting emphasis on inspection and accountability in the name of 'quality'. Yet dysfunction, stress, and the pressure to compete are widely compromising the quality of educational experience and the lives of educators and learners. Thirdly, governments are concerned about the 'socially excluded', drop-outs from schooling and 'failing' schools and higher education institutions; yet policies which force 
institutions to compete mean that the advantaged ones get better and richer while the disadvantaged ones become more disadvantaged and receive blame for failing. [3] (p. 21)

These concerns are not new, but their relevance is new, or is at least being renewed with increased urgency. Up to the last quarter of the 20th century, schooling could operate with the traditional idea of transmitting knowledge and practices from the experienced and skilled (adults, experts) to the inexperienced and unskilled (children and youth). Although harshly criticized at times, this generic idea prevailed. A call for a new pedagogy, even a cry as in Woods Hole in 1959, did not challenge this understanding of schooling.

\section{PACK and Sustainability}

Now, however, with the climate crisis hanging over the entire globe as a result of the actions of those most experienced and skilled, the conventional understanding of education can no longer be accepted. People know what changes are needed, but those standing in the way of change are the adults, the generations claiming both experience and skill. No wonder that Greta Thunberg has complained about the inaction of politicians by saying: "We teenagers and children shouldn't have to take the responsibility. But right now the world leaders keep acting like children and somebody needs to be the adult in the room". In line with this demand for change, we propose a rendering of the PACK that not only gives a different answer to each of the questions but also reverses the order in which it is read (see Table 3).

Table 3. The PACK with a transformative understanding of educational design.

\begin{tabular}{|c|c|c|c|c|}
\hline & $\begin{array}{c}\text { P } \\
\text { Pedagogy }\end{array}$ & $\begin{array}{c}\text { A } \\
\text { Assessment }\end{array}$ & $\begin{array}{c}\mathrm{C} \\
\text { Curriculum }\end{array}$ & $\begin{array}{c}\mathrm{K} \\
\text { Knowledge }\end{array}$ \\
\hline Gadgets & $\begin{array}{l}\text { How do we teach } \\
\text { students? }\end{array}$ & $\begin{array}{c}\text { How do we evaluate } \\
\text { learning? }\end{array}$ & What is to be taught? & $\begin{array}{c}\text { What knowledge is } \\
\text { needed? }\end{array}$ \\
\hline $\begin{array}{l}\text { Conventional } \\
\text { understanding }\end{array}$ & $\begin{array}{l}\text { Presentation of } \\
\text { established knowledge } \\
\text { and training for skills. }\end{array}$ & $\begin{array}{l}\text { Student is assessed, } \\
\text { either formatively or } \\
\text { summatively. }\end{array}$ & $\begin{array}{l}\text { Curriculum defines } \\
\text { objectives and content } \\
\text { of education. }\end{array}$ & $\begin{array}{l}\text { Knowledge building as } \\
\text { an accumulation of } \\
\text { established knowledge } \\
\text { and skills. }\end{array}$ \\
\hline $\begin{array}{l}\text { Transformative } \\
\text { understanding }\end{array}$ & $\begin{array}{l}\text { Engage with students } \\
\text { in a collaborative } \\
\text { setting. }\end{array}$ & $\begin{array}{l}\text { Students and teachers } \\
\text { together assess the } \\
\text { process of learning. }\end{array}$ & $\begin{array}{l}\text { Objectives of education } \\
\text { are identified through } \\
\text { collaborative learning. }\end{array}$ & $\begin{array}{l}\text { Knowledge building is } \\
\text { more about conceptual } \\
\text { change and } \\
\text { transformation. }\end{array}$ \\
\hline
\end{tabular}

The conventional understanding of educational design moves from right-to-left, beginning with an expert definition of relevant knowledge and ending with devising a pedagogy that meets the predefined goals. We suggest that educational change should begin by altering the pedagogy and aiming for transformation, i.e., beginning furthest to the left and then moving right:

(P) develop a pedagogy where teachers and students meet in a collaborative setting to learn from each other, and

(A) jointly assess the quality and the outcome of the educational activity according to measures that are developed as part of the educational activity,

(C) while working towards objectives that are at least partly defined through a collaborative learning process, which

(K) aims to change learners' conception of themselves and the world.

The change from the conventional understanding to the transformative understanding is thorough in terms of content, method, roles of those involved, and underlying values. Thus, what we are suggesting is not an amendment or what many would call reform, but a thorough change in the very idea of education and how it is approached in formal settings.

The gadgets that we placed in the PACK, the four questions guiding us through the challenging educational landscapes, are also helpful in mapping out different understandings of sustainability education. The distinction between the conventional and 
transformative understanding of the PACK resembles differences that have been observed among different interpretations of education for sustainable development (or variants thereof, such as Sustainability Education (SE) or Environmental and Sustainability Education (ESE)). In a short opinion essay in the Journal of Education for Sustainable Development, Paul Vare and William Scott distinguished between ESD 1 and ESD 2 [17]. They described the former in the following way:

ESD 1 fits with the received view of sustainable development as being expertknowledge-driven where the role of the nonexpert is to do as guided with as much grace as can be mustered. Some see this as UNESCO's view, and what-by and large- -is driving the UN Decade of ESD, pointing, for example, to the section of the UN Decade's implementation plan (UNESCO 2005) which says: 'The DESD promotes a set of underlying values, relational processes and behavioral outcomes, which should characterize learning in all circumstances.' [17] (p. 193)

ESD 1 corresponds to the conventional understanding of the PACK, proceeding from expert knowledge (furthest to the right) and then moving to curriculum design (C), where the expert knowledge is given an educational interpretation, such as in the UN DESD implementation plan. Then, a means of evaluating whether the desired outcomes had been reached would be devised (A) and finally some educational activities (P) would be developed.

What Vare and Scott refer to as ESD 2, on the other hand, is not about reaching certain pre-defined goals but locating sustainable development within the learning process itself:

Some will see this as a case of double-loop learning, where we learn to do different things to be more effective. Examples include thinking about what 'being more sustainable' means. ... From this perspective, sustainable development doesn't just depend on learning; it is inherently a learning process. [17] (p. 194)

A little later they add:

This way of thinking about sustainable development encapsulates the core role for learning as a collaborative and reflective process and captures the intergenerational dimension and the idea of environmental limits. [17] (p. 194)

The move from expert-driven education — where the value and quality of the learning process is measured against predefined learning outcomes (ESD 1) - to focusing more on the learning process itself (ESD 2) resembles moving from a conventional interpretation of the PACK to a transformational understanding.

We also find useful the distinction that Arjen E. J. Wals makes between 'instrumental environmental education' and 'emancipatory environmental education'. About the former, he says:

Much environmental education aims at changing learner behavior, including attitudes, beliefs, and values. Many environmental education researchers and practitioners try to structure environmental education by using hierarchical levels of universal goals and measurable learning outcomes (see for instance: Hungerford and Volk 1990). It is no surprise that within an environmental education that seeks to change 'learner behavior', the establishment of knowledge and awareness of nature and environment, and the application of what is learned, are considered essential steps in the learning process. Evaluation of the achievement of these goals is considered crucial for determining the success of environmental education and, incidentally, for justifying government spending on EE. [18] (p. 177)

Arjen then contrasts the instrumental perspective with emancipatory perspective: If a key function of education is fostering autonomous thinking about, among other things, environmental issues, then it would be contradictory to prescribe behavioral outcomes triggered by a learning activity or sequence of activities. [18] (p. 177)

He then goes on to refer to Bob Jickling who, in his paper "Why I don't want my children to be educated for sustainable development" [19], says (a) that such education is 
too instrumental at the expense of meaningful education, (b) that the contestability of the concept of sustainable development makes it questionable as an aim in education, and (c) that a prescription of a particular outlook conflicts with the development of autonomous thinking [18] (p. 179).

The distinction between ESD 1 and ESD 2 that Vare and Scott make resembles the distinction between the instrumental and the emancipatory perspective described by Wals and our conventional vs. transformative understanding of the PACK. The significance that Vare and Scott attach to their distinction is, however, very different from the way both Wals sees his distinction and our understanding of the different understandings of the PACK.

Vare and Scott say that ESD 1 and ESD 2 might complement each other, arguing that "the ancient Chinese concept of Yin and Yang ... provides a more appropriate heuristic" [17] (p. 195) than seeing them as competing or at odds with each other. Wals disagrees, arguing that these two kinds of approaches are fundamentally different and will not be brought into any kind of harmony. In summing up the difference between the technical and the emancipatory approaches, Wals says:

In summary, an instrumental approach assumes that a desired behavioral outcome of an environmental education activity is known, more or less agreed upon, and can be influenced by carefully designed interventions. Conversely, an emancipatory approach assumes that the dynamics of our world are such that citizens need to become engaged in an active dialogue to establish co-owned objectives, shared meanings, and a joint, self-determined plan of action to make changes they themselves consider desirable and of which the government hopes will, ultimately, contribute to a more sustainable society as a whole .. . [18] (p. 180)

We are skeptical of the Yin-Yang idea of Vare and Scott, the point being that these approaches are based on contradictory values, support fundamentally different visions of education, and favor methods and organization that follow different principles. It may well be that the reality of educators "on the ground" requires them to oscillate between ESD 1 and ESD 2-or that they go from school subjects where knowledge is predefined, the curriculum is rigid, and assessment is based on predefined learning outcomes (reading the PACK from right-to-left) to educational settings where the reality is more praxis guided (the PACK is read from left-to-right). An educator in such a position will need to find a balance between the two but such a balance will be more like learning to adapt to incompatible demands rather than finding a Yin-Yang harmony.

\section{SE and Knowledge Structures}

To highlight the contrast between the conventional and the transformative understanding of the PACK, we find it useful to draw on a distinction that Basil Bernstein made around the turn of the century between vertical and horizontal discourses and knowledge structures. Making this distinction, Bernstein says:

Briefly a Vertical discourse takes the form of a coherent, explicit and systematically principled structure, hierarchically organised as in the sciences, or it takes the form of a series of specialised languages with specialised modes of interrogation and specialised criteria for the production and circulation of texts as in the social sciences and humanities. [20] (p. 157)

Bernstein then considers how knowledge is distributed within this kind of discourse, saying:

In the case of Vertical discourse there are strong distributive rules regulating access, regulating transmission and regulating evaluation. Circulation is accomplished usually through explicit forms of recontextualising affecting distribution in terms of time, space and actors. [20] (p. 157)

The way Bernstein describes knowledge distribution within vertical discourse fits our description of reading the PACK from right-to-left. The crucial thing is that vertical knowledge is explicitly structured based on principles belonging to the discourse itself. 
An example might be mathematics or biology, where there is a clear sense of going from simpler to more complex issues, and where things get organized based on mathematical or biological principles rather than factors external to the field of study.

Unlike vertical discourse, which is systemic and often expert-driven or at least expertorganized, horizontal discourse is less structured and there is no authoritative voice (no expert) defining relevant knowledge or educational objectives.

[Horizontal discourse] is likely to be oral, local, context dependent and specific, tacit, multi-layered and contradictory across but not within contexts. However, from the point of view to be taken here, the crucial feature is that it is segmentally organised. By segmental I am referring to the sites of realisation of this discourse. [20] (p. 257)

What Bernstein means by 'segmental' in this context is that the discourse does not form a unified whole (like mathematics) in terms of some overarching principle or purpose, but rather that it consists of different segments that are connected through principles, conventions, or practices that lie outside the discourse itself.

Our intention in bringing these distinctions from Bernstein to bear on the different understandings of sustainability education (ESD 1/ESD 2 and technical/emancipatory approach) is to emphasize how fundamentally different they are. Reading the PACK from right-to-left gives us an image of a vertical knowledge structure, while reading it from left-to-right leads to horizontal structures where knowledge is going to be segmentally organized. Our own distinction between the two readings of the PACK (right-to-left vs. left-to-right) applies not only to sustainability education but to education quite generally.

Although the overall structure of the pedagogical design must be segmental, this does not mean that vertical knowledge is eliminated. Within the horizontal knowledge structure, there will be segments constituted by vertical knowledge structures, such as mathematics or biology. These segments are, however, organized and their very presence is justified by principles that lie outside these segments themselves.

\section{PACK and Global Educational Reform}

The gadgets that were placed in our PACK are tools helping teachers on their way towards 2030. Although many set out with high hopes, we realize that there is no clear path to follow. These gadgets are helpful for making new policy, or reflecting on ongoing policy development, at both national and global levels.

Teachers who take their role as sustainability educators seriously-as change-makers in the life of young people-face various challenges, some of which are 'conventional problems in education': groups that are too large, too many things to teach, too little time, facilities and equipment that are outdated, a lack of support, etc. Such challenges are common, affecting all strands of education, and although teachers who work on issues that are transdisciplinary or multidisciplinary may struggle more, they are essentially facing the same problems. These are all problems of scarcity: too little of something, whether time, people, money, or space. Addressing these problems has led to responses such as the Global Educational Reform Movement (GERM) [21] (p. 1). Describing this movement, the Finnish scholar Pasi Sahlberg notes five features: (1) "increased competition between schools for enrolment", (2) "standardization of teaching and learning in schools", (3) "increased emphasis on reading literacy, mathematics, and science in schools", (4) "borrowing of change models from the corporate world as a main means of improvement", and (5) "adoption of test-based accountability policies that hold teachers and schools to account for students' achievement in schools [10] (pp. 195-199). All these features are indicative of a conventional understanding of education, which one gets by reading the PACK backwards, pushing for ESD 1 rather than ESD 2, or what Wals describes as a technical approach rather than an emancipatory one. Thus, governmental responses to the abovementioned problems of scarcity in education only entrench the conventional educational paradigm that has proven to be unfit for addressing current global crises. Stephen Sterling aptly points this out in the following text: 
Within this [conventional] paradigm, most mainstream education sustains unsustainability - through uncritically reproducing norms, by fragmenting understanding, by sieving winners and losers, by recognizing only narrow parts of the spectrum of human ability and need, by an inability to explore alternatives, by rewarding dependency and conformity, and by servicing the consumerist machine. [3] (pp. 14-15)

Thus, we are left with the paradoxical situation that, during the last few decades, educational change-or reform-across the globe, not least in the affluent west, has moved away from meaningful sustainability education while, at the same time, sustainability has become an ever more pronounced goal of education.

\section{PACK and Local Education}

The PACK is not only a device to rationalize educational change from a distance but should also be useful for educators "on the ground" who need to reflect on their own praxis and maintain professional integrity in circumstances where they may find external conditions and demands encroaching on them and compromising their ability to live up to being good teachers $[10,13,15]$. Apart from the large-scale challenges that schools and teachers face, often exaggerated by the GERM ideology, there are also other challenges (not unrelated) that affect teaching more locally [22,23]. We will discuss three such challenges and frame them in terms of challenges to sustainability education:

(1) The challenge of conflicting values: Since the moral and political values that underpin sustainability are contested, teachers may find it difficult to make them explicit in working with students;

(2) The challenge of motivation: In so far as the values that underlie SE are universal and global, students may find them distant and without the motivational force needed in education; and

(3) The challenge of uncertainty: Sustainable education aims for something that has never existed and, thus, no one really knows what to aim for.

Although we frame these challenges as arising in the context of sustainability education, we believe that they actually arise for any form of critical education. Part of the "virtue" of the conventional educational paradigm is that it avoids these challenges or silences them; by leaving the starting point of educational change or design up to expert knowledge (K), the curricula (C) then lay out the design as if education can be pursued as either value-free praxis or as based on universally agreed values (defined by the experts). Assessment and pedagogy are then instrumentally justified in terms of the expert-defined knowledge and the ensuing curricula. However, this "virtue" of the conventional paradigm is perhaps its biggest vice. Before we begin to address these challenges, we will spell them out in more detail.

(1) The challenge of conflicting values: The comprehensive, distributed project of aiming for sustainable living on a small planet, densely populated by humans and nonhuman living organisms, is a project infused with fundamental philosophical questions. It is not about finding a way for many to survive but for all people to lead the good life. It is not about sustaining the way things are at present but about sustaining a different world, one in which everyone has a fair chance of living the good life. This will only be possible if humans learn to live in harmony with each other and the non-human world. Put this way, aiming for sustainability is not only aiming for a moving target, but aiming for a target that we have not yet seen. We can certainly roll the clock back to times when human living was well within the limits of the Earth, but that does not constitute a solution to the present challenge, for during those times living on planet Earth was very different from the life we have today.

Since people disagree profoundly on what constitutes the good life, ordinary teachers who want to take sustainability seriously find themselves in the deep waters of normativity and values education. They may not know where the limits are between staying within the boundaries of reasonable pluralism or transgressing those limits. Among the cornerstones 
of liberal political philosophy and liberal education is the principle that public institutions, including schools, should not take a stance on controversial values [24]. Aiming for sustainability might, however, require teachers to take exactly such a stance; to be partial to different and conflicting values. This raises the following questions:

(Q1) Must teachers find a way of staying neutral concerning competing philosophies of life? Or should they rather favor a particular philosophy of life-or some set of such philosophies - that align with the project of aiming for sustainability?

The challenge is not a technical one; it is not something teachers or policy-makers can solve by adopting certain teaching techniques or reorganizing school practices, but requires profound discussion of the very role of education in the contemporary world.

(2) The challenge of motivation: This challenge derives from the universal or general nature of many of the values that underlie the project of creating a sustainable world. To catch the attention of students in schools-whether they are kids in primary schools or students at universities - teachers are encouraged to connect the material with students' interests and daily lives. Well, what are their interests? Young people take interest in a great variety of things; some are truly concerned with the ecological status of the planet and the social and political fabric of contemporary societies [25,26], while others are rather concerned with sighted or self-oriented interests and consumeristic goods, pulled along by an ideology based on competition and opulence. In recent decades, this consumeristic ideology has influenced education ever more $[3,13]$. So, teachers face the challenge of making a larger pool of people feel the urgency of the present state of the world and helping them see how attending to those issues might be a meaningful endeavor while strong social forces pull in a contrary direction.

One might think that it should not be so difficult to move people into living more sustainable lives since, after all, most people have a reasonable sense of justice. The grave injustices caused by the large-scale and global degradation of the natural environment ought to be motivating. However, things are not so straight forward, since the entire market of consumer goods pulls in the opposite direction by entrenching an ideology of competition, consumerism, and opulence (see [13] and other papers in the same issue of Environmental Education Research).

Teachers and educators in general will not advance very much if the project of sustainability makes little sense to students (and learners in general, in and out of formal settings) and if people perceive sustainable living as a life in regulated austerity. Such living will not be seen as a way of leading and sustaining a good life but, at best, avoiding catastrophes. So, another question arises:

(Q2) How can learners come to see sustainable living as constituting a good life rather than as symptomatic of a life in austerity?

(3) The challenge of uncertainty: Traditionally, education has been about delivering answers; textbooks are full of answers-representing what the (K) stands for in the conventional framing of the PACK - and conventional assessment is concerned with assessing whether the students have learned those answers. Now, however, for the first time in history, the conventional answers have proved to be faulty-countries in the West, with their great educational systems, are among those who cause the most damage to the global ecosystem (see, e.g., the global footprint network), and they are also the ones that drive and maintain the North-South disparity (as recently evident in access to vaccines for COVID-19) [27]. Thus, education faces unprecedented uncertainty but is, at the same time, called on as a response to this very uncertainty.

The challenge of uncertainty derives from the two previously mentioned challenges and moves the discussion to more concrete issues of learning: What? How? Why? Educators must find ways of organizing students' activities around something tangible and justify it with reference to something that at least looks like a respectable educational objective. The activity could be reading or writing something, or an observation of a phenomenon, or a philosophical discussion, or a project inside or outside the classroom. What should these 
be? How can they be justified in the absence of both a definitive knowledge base and an ultimate objective of education? This leads us to the following question:

(Q3) In what kinds of educational activities can teachers engage their students in order to support the project of sustainability?

These three challenges situate the project of aiming for sustainability in a wide context that extends to speculative, philosophical considerations about the good life and to practical issues about concrete educational design and activities for teachers. The first challenge, that of conflicting values, concerns the question: On which values can SE be grounded? The second challenge, that of motivation, invites the question: How can students be motivated to engage in SE? The third challenge has to do with pedagogy and concerns the question: What is an appropriate pedagogy for SE?

\section{PACKing a New Pedagogy}

In the PACK, we have placed four gadgets in the form of questions: How do we teach students? How do we evaluate learning? What is to be taught? and What knowledge is needed? As we explained at the outset, one can respond to these questions in a conventional way and thereby solidify the conventional educational paradigm, or one can offer a transformative response in the spirit of sustainability education [14,27-29]. The latter does not simply call for an amendment to the conventional understanding but suggests a thorough overhaul of the conventional educational paradigm. When we suggest that the PACK be read left-to-right, rather than the other way around, the question that guides the way is not about the required knowledge or skill, but about pedagogy. Within the conventional understanding, questions about pedagogy are subordinate to questions about required knowledge and skill. This has led to a flurry of all sorts of toolboxes for teachers, programs, and other 'practical' manuals for teaching. In his book about the irregular school, Roger Slee remarks this trend:

Together with the proliferation of reductive targets for schools and teachers, these manuals are one in an array of symptoms of atrophy in the leadership and management of schooling, and education. [30] (p. 3)

An educational manual, whether a do-it-yourself guide or a teacher guide to use in the classroom, usually presupposes an objective for the proposed educational activities. Such manuals may be of help in a vertical knowledge structure, to use the concept from Bernstein, for within such structures an organizing principle is already given. A manual can, for instance, help a student get acquainted with the foundations before advancing up into the more complex aspects of the knowledge structure in question. Sustainability education does, however, not form a vertical knowledge structure but a horizontal one, which calls for a pedagogy that must be what Bernstein refers to as segmental. Describing the modes of acquisition within horizontal discourse, Bernstein says:

... the pedagogic interventions, in turn, are a function of the different 'knowledges' required to be acquired. These 'knowledges' are related not by integration of their meanings by some coordinating principle, but the 'knowledges' are related through the functional relations of segments or contexts to the everyday life. It follows then that what is acquired in one segment or context, and how it is acquired, may bear no relation to what is acquired or how it is acquired in another segment or context. Learning how to tie up one's shoes bears no relation to how to use the lavatory correctly. These competences are segmentally related. They are not related by any principle integrating their specific acquisitional 'knowledge'. [20] (pp. 158-159)

Bernstein then goes on to describe a 'segmental pedagogy' that "is usually carried out in face to face relations with a strong affective loading as in the family, peer group or local community. The pedagogy may be tacitly transmitted by modelling, by showing or by explicit modes." This situation calls for something new. Education must challenge conventional truths and practices, question established privileges, overthrow conventional attitudes, and establish new systems of values [3,14-16,27,30-32]. Given the first challenge, 
that of conflicting values, such education must be situated in the tension zone, facing not only the fact of plurality — as a liberal theory such as that of Rawls suggests—but the fact of disagreement and conflict, as Chantal Mouffe argues with respect to democracy [33].

Given this fact of disagreement and conflict, uncertainty is an unavoidable feature of educational design. Teachers must accept the fact of uncertainty as an unavoidable condition of their work and students must accept it as an unavoidable characteristic of their educational settings, both with regard to means and ends. What emerges is a challenging dilemma. At the same time as education must be for change, we do not yet know what that change looks like. Yet, this is the very fact from which educational change must proceed. There is no knowledge that can eliminate this uncertainty, and the only thing educators can do is to turn it into an educational opportunity. A pedagogy that does that is unavoidably segmental in Bernstein's sense, and radically so: Only some of the segments can be identified beforehand; the rest must be discovered and developed along the way.

\section{Concluding Remarks-UnPACKing at the End of the Day}

Conventional education invites teachers to travel along various well-worn paths. The landscape may be challenging, the terrain may be harsh, and although it may take a trained eye to find the "right" path, it is there and at the end of it is a destination waiting to be reached. Not only are teachers trained according to this paradigm, but their own experience from school, from early age up through tertiary education, confirms this. However, those well-worn paths do not lead to the sort of 2030 that we want to see. This is why the climate crisis translates directly into crisis in education. The word 'crisis' comes from the ancient Greek word 'krísis', which means a point in time where a decision needs to be made. With the tipping point in sight, we are already at a turning point. We have to make a decision to turn off the path along which we have been traveling and head into a place where there are no paths, no road signs, no milestones, and even the destination is unclear. We will have to head uphill instead of continuing along the lowlands, and we will have to convince our students to come along, help us develop a vison of a desired destination, and figure out how to get there. At the end of the day, when we unpack and put up our tents, we may ask:

What have we learned today? (K)

Did we achieve something worthwhile? (C)

How was the day? (A)

What was the mode of travel? $(\mathrm{P})$

These questions arise as reflective questions helping the group as a whole to figure out whether we are on a course towards an acceptable 2030 — even a desirable 2030. If so, we might be reasonably confident that our walks through the uncharted territory constitute a worthwhile activity, even a part of the good life.

Author Contributions: Conceptualization, Ó.P.J. and A.M.; resources, Ó.P.J. and A.M.; writingoriginal draft preparation, Ó.P.J. and A.M.; writing—review and editing, Ó.P.J. All authors have read and agreed to the published version of the manuscript.

Funding: This research received no external funding.

Institutional Review Board Statement: Not applicable.

Informed Consent Statement: Not applicable.

Data Availability Statement: Not applicable.

Conflicts of Interest: The authors declare no conflict of interest.

\section{References}

1. Hook, L. Greta Thunberg: 'It Just Spiralled out of Control'. Financial Times. 31 March 2021. Available online: https://www.ft. com/content/6ee4bb03-3039-446a-997f-91a7aef5f137 (accessed on 3 December 2021).

2. Fillmore, L.W.; Snow, C.E. What Teachers Need to Know about Language; Office of Educational Research and Improvement: Washington, DC, USA, 2000. Available online: http:/ / files.eric.ed.gov/fulltext/ED444379.pdf (accessed on 3 December 2021).

3. Sterling, S. Sustainable Education: Re-Visioning Learning and Change; Green Books: Dartington, UK, 2001. 
4. Bruner, J. The Process of Education; Harvard University Press: Cambridge, MA, USA, 1960.

5. Sigurðardóttir, A. Professional learning community in relation to school effectiveness. Scand. J. Educ. Res. 2010, 54, 395-412. [CrossRef]

6. Dewey, J. Democracy and Education; Macmillan: New York, NY, USA, 1916.

7. Dewey, J. Creative democracy, the task before us. In John Dewey: The Later Works, 1925-1953; Boydston, J., Ed.; Southern Illinois University Press: Carbondale, IL, USA, 1976; Volume 14, pp. 224-230. (Original work published 1939).

8. Biesta, G.J.J. Beyond Learning: Democratic Education for a Human Future; Paradigm: Boulder, CO, USA, 2006.

9. Biesta, G.J.J.; Lawry, R. From teaching citizenship to learning democracy: Overcoming individualism in research, policy and practice. Camb. J. Educ. 2006, 36, 63-79. [CrossRef]

10. Sahlberg, P. The Global Educational Reform Movement and its impact on schooling. In The Handbook of Global Education Policy; John Wiley \& Sons: Chichester, UK, 2016; pp. 128-144.

11. Babtista, J.A. Eco(il)logical knowledge: On different ways of relating with the known. Environ. Humanit. 2018, 10, 397-420. [CrossRef]

12. Lagemann, E.C. The Plural Worlds of Educational Research. Hist. Educ. Q. 1989, 29, 185-214. [CrossRef]

13. Hursh, D.; Henderson, J.; Greenwood, D. Environmental education in a neoliberal climate. Environ. Educ. Res. 2015, 21, 299-318. [CrossRef]

14. Jónsson, Ó.P.; Guðmundsson, B.; Øyehaug, A.B.; Didham, R.J.; Wolff, L.-A.; Bengtsson, S.; Lysgaard, J.A.; Gunnarsdóttir, B.S.; Árnadóttir, S.M.; Rømoen, J.; et al. Mapping Education for Sustainability in the Nordic Countries; TemaNord 2021:511; Nordic Council of Ministers: Copenhagen, Denmark, 2021. [CrossRef]

15. Jónsson, Ó.; Thorsteinsson, J.; Árnadóttir, H.; Gísladóttir, K. On being in nature: Aldo Leopold as an Educator for the 21st Century. Philos. Inq. Educ. 2020, 27, 106-121. Available online: https://journals.sfu.ca/pie/index.php/pie/article/view/1219 (accessed on 3 December 2021). [CrossRef]

16. Orr, D.W. Earth in Mind: On Education, Environment, and the Human Prospect, 10th ed.; Island Press: London, UK, 2004.

17. Vare, P.; Scott, W. Learning for a change: Exploring the relationship between education and sustainable development. J. Educ. Sustain. Dev. 2007, 1, 191-198. [CrossRef]

18. Wals, A.E.J. Learning our way to sustainability. J. Educ. Sustain. Dev. 2011, 5, 177-186. [CrossRef]

19. Jickling, B. Why I don't want my children to be educated for sustainable development. J. Environ. Educ. 2010, 23, 5-8. [CrossRef]

20. Bernstein, B. Pedagogy, Symbolic Control and Identity: Theory, Research, Critique; Rowman \& Littlefield: Oxford, UK, 2000.

21. Hargreaves, A.; Earl, L.M.; Moore, S.; Manning, S. Learning to Change. Teaching beyond Subjects and Standards; Jossey-Bass: San Francisco, CA, USA, 2001.

22. Öhman, J. New ethical challenges within environmental and sustainability education. Environ. Educ. Res. 2016, 22, 765-770. Available online: https:/ / www.tandfonline.com/toc/ceer20/22/6 (accessed on 3 December 2021). [CrossRef]

23. Sund, L. Facing global sustainability issues: Teachers' experiences of their own practices in environmental and sustaina-bility education. Environ. Educ. Res. 2016, 22, 788-805. [CrossRef]

24. Rawls, J. Justice as Fairness; Harvard University Press: Cambridge, MA, USA, 2001.

25. Kember, D.; Ho, A.; Hong, C. The importance of establishing relevance in motivating student learning. Act. Learn. High. Educ. 2008, 9, 249-263. [CrossRef]

26. Ravnbøl, K.; Neergaard, I. Nordic Youth as Sustainable Changemakers: In the Transition to Sustainable Consumption and Production; Nordic Council of Ministers: Copenhagen, Denmark, 2019. [CrossRef]

27. Wolff, L.-A. Sustainability Education in Risks and Crises: Lessons from Covid-19. Sustainability 2020, 12, 5205. [CrossRef]

28. Bonnett, M. Education for sustainability as a frame of mind. Environ. Educ. Res. 2002, 8, 9-20. [CrossRef]

29. Herranen, J.; Vesterinen, V.-M.; Aksela, M. From Learner-Centered to Learner-Driven Sustainability Education. Sustainability 2018, 10, 2190. [CrossRef]

30. Slee, R. The Irregular School and Society: Exclusion, Schooling and Inclusive Education; Routledge: London, UK, 2011.

31. Jordan, K.; Kristjánsson, K. Sustainability, virtue ethics, and the virtue of harmony with nature. Environ. Educ. Res. 2017, 23, 1205-1229. [CrossRef]

32. Vargas, R.I.; Temper, L.; Sterlin, J.; Smolyar, N.L.; Sellers, S.; Moore, M.; Melgar-Melgar, R.; Larson, J.; Horner, C.; Erickson, J.D.; et al. From the Anthropocene to Mutual Thriving: An Agenda for Higher Education in the Ecozoic. Sustainability 2019, 11, 3312. [CrossRef]

33. Mouffe, C. Deliberative Democracy or Agonistic Pluralism? Soc. Res. 1999, 66, 745-758. Available online: http:/ /www.jstor.org/ stable/40971349 (accessed on 3 December 2021). 